DOI :10.31357/fapsmst.2010.00515

\title{
PRELIMINARY STUDY ON STANDARDIZATION OF KUSHMANDA AVALEHA/RASAYANA
}

MUMTAZ SHIFA PALLIE

Submitted in partial fulfillment of the requirement for the award of the degree of

MASTER OF SCIENCE IN INDUSTRIAL UTILIZATION OF MEDICINAL AND AROMATIC PLANTS

of the

UNIVERSITY OF SRI JAYEWARDENEPURA

SRI LANKA

2010 


\section{DECLARATION}

I do hereby declare that the work reported in this project report/thesis was exclusively carried out by me under the supervision of Prof. Ajith Abeysekera. It describes the result of my own independent research except where due reference has been made in the text. No part of this project report/thesis has been submitted earlier or concurrently for the same or any other degree.

…03/.08./2010...

Date

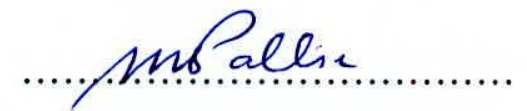

Signature of the candidate

Certified by:

1. Supervisor - Prof.A.M.Abeysekera

Date:

(Signature):

2. Co - Supervisor - Dr.C.Mahatanthila

Date:

(Signature): 


\begin{abstract}
Mass production of ayurvedic drugs at industrial scale is rapidly increasing due to the popularity of herbal medicine. The effectiveness of these drugs depends on the quality of raw materials, accuracy of in-process techniques and suitable storage of the final product. Hence standardization of ayurvedic drugs has become a requisite in ayurvedic drug industry.
\end{abstract}

This research is a preliminary study performed on standardization of Kushmanda avaleha, an ayurvedic formulation used mainly for rejuvenation therapy. Five market preparations and one standard drug prepared in the laboratory according to the text Sharangadhara samhita as the reference drug was used for this study. The parameters included organoleptic characters and physico-chemical analysis. Chromatographic analysis was performed on the volatile component of the drug.

Results from the chemical tests suggested that there were variations in different market brands. Total ash content ranged from $0.3605 \%-1.6741 \%$. Reference drug had the least value for total ash. This test gives an idea about the purity of the medicine. Values for methanol extractable matter ranged from $47.2674 \%-71.1792 \%$, reference drug had the highest value. Ethanol insoluble macro molecular fraction ranged from $1.3138 \%-33.6013 \%$. The reference drug had a mean value of $22.2686 \%$. In the cos chromatograms of each brand, certain peaks correspond with each other, but majority of peaks did not. Even the peaks which did correspond with that of the reference drug had different peak areas.

Due to all these facts it becomes clear that the quality of different brands of Kushmanda avaleha in the market varies widely and that there is a need to develop standard parameters to ensure methods of quality control. 


\section{ACKNOWLEDGEMENT}

I would like to place my deepest gratitude to my supervisor Prof. A.M. Abeysekera, Dean, faculty of Applied science, University of Sri Jayewardenepura, Nugegoda, for his valuable advice and guidance provided throughout the study and for giving much needed inspiration and encouragement to successfully complete this project.

I would also wish to thank Dr. C. Mahatanthila, Co-supervisor, lecturer, faculty of Applied science, University of Sri Jayewardenepura, for the support and guidance given to me during the research project.

I record my sincere thanks to Prof. S.I. Samarasinghe, Course coordinator, lecturer, faculty of Applied science, University of Sri Jayewardenepura, Nugegoda, for giving much needed support to carry out experiments which were needed to successfully complete this project.

I express my deep gratitude to Dr. S.D. Chinthaka, lecturer, faculty of Applied science, University of Sri Jayewardenepura, Nugegoda, for giving me much support and guidance during the performance of gas chromatography.

I wish to express my sincere thanks to Mrs. Ramya, Mr. Sisra Weerasinghe, Mr. Chanaka Karunarathna, and all other non-academic staff of the department of Chemistry, University of Sri Jayewardenepura, Nugegoda, who gave support to carry out my laboratory work successfully.

I would also like to give my special thanks to Mr.Suranga Rajapaksha, Assistant lecturer, department of Chemistry, University of Sri Jayewardenepura, Nugegoda, for giving me the support to compile my thesis accurately as possible. 
I wish to thank Dr. Swarna Hapuarachchi, senior lecturer, department of Materia medica, Institute of indigenous medicine, University of Colombo, and all the non-academic staff of the department of Materia medica, for facilitating me to carry nut laboratory work.

I wish to express my sincere gratitude to Dr. Kelum Amarakoon who never fails to inspire me in all that I do and also my family for being a source of encouragement.

Finally, I would like to thank all others who helped me in numerous ways to make this study a success. 
Table of Contents

Declaration $\quad$ ii

Abstract

Acknowledgment

Table of contents vi

List of Tables $\quad$ xi

List of Figures $\quad$ xii

Meaning of Sanskrit words $\quad$ xiii

\section{CONTENT}

\section{CHAPTER 1 - INTRODUCTION}

1.1 Evolution of Ayurvedic Drug preparation and the present state 01

$\begin{array}{ll}1.2 \text { Need for standardization } & 03\end{array}$

1.3 Ayurveda drug standardization 06

$\begin{array}{lll}\text { 1.3.1 Drug standard } & 06\end{array}$

1.3.2 Problem of setting up standards 08

$\begin{array}{lll}\text { 1.3.3 Drug standardization } & 10\end{array}$

1.4 Introduction on Avaleha Kalpana 11

1.4.1 Etymological derivation of the word avaleha 12

1.4.2 Synonyms for the word avaleha 12

1.4.3 Basic materials needed for the preparation of avaleha 12

1.4.3.1 Liquid Substance (Drava dravya) 13

1.4.3.2 Sweet Substance (Madhura dravya) 13

1.4.3.3 Condiments (Prakshepa dravya) 14 
1.4.4 General pharmaceutical procedure underlying the preparation of avaleha

1.4.5 Parameters for in-process validation

1.4.6 Storage, dose, vehicle (Anupana) and method of administration 16

1.5 Kushmanda Avaleha/Rasayana

1.5.1 Description of ingredients of Kushmanda avaleha

1.5.1.1 Benincasa hispida (Thunb.) Cogn

(Family CUCURBITACEAE)

1.5.1.2 Piper longum L. (Family PIPERACEAE) 21

1.5.1.3 Cuminum cyminum L. (Family APIACEAE) 22

1.5.1.4 Zingiber officinale Roscoe. (Family ZINGIBERACEAE) 23

1.5.1.5 Cinnamomum zeylanicum Blume. (Family LAURACEAE) 25

1.5.1.6 Elettaria cardamomum L.Maton (Family ZINGIBERACEAE) 26

1.5.1.7 Piper nigrum L. (Family PIPERACEAE) 28

1.5.1.8 Pogostemon heyneanus Benth. (Family LAMIACEAE) 29

1.5.1.9 Coriandrum sativum L. (Family APIACEAE) 30

1.5.1.10 Sugar (Saccharum officinarum L. - Family POACEAE) 31

1.5.1.11 Clarified Butter/Ghee (Ghrita) 32

1.5.1.12 Bee honey (Madhu) 33

1.5.2 Main volatile components in Kushmanda avaleha 34

1.5.3 Method of preparation of Kushmanda avaleha 36

1.5.4 Properties of Kushmanda avaleha 36

1.5.5 Storage, dose and vehicle (Anupana) 36 


\section{CHAPTER 2 - MATERIALS AND METHODS}

2.1 Instruments and chemicals $\quad 38$

2.2 Reference drug preparation $\quad 39$

2.2.1 Specification of raw materials $\quad 39$

2.2.2 Pre-processing of raw materials $\quad 40$

$\begin{array}{lll}\text { 2.2.3 Processing technique } & 40\end{array}$

2.2.4 Finished product 41

2.3 Comparative study of different brands of drugs with the reference drug $\quad 41$

2.3.1 Organoleptic evaluation 41

2.3.2 Chemical tests 41

2.3.2.1 Determination of total ash content 42

2.3.2.2 Determination of methanol extractable matter (hot extraction) $\quad 43$

2.3.2.3 Determination of ethanol insoluble macro-molecular fraction $\quad 44$

$\begin{array}{ll}\text { 2.3.3 Chromatographic analysis } & 45\end{array}$

2.3.3.1 Thin layer chromatography performed on methanol extracts $\quad 45$

2.3.3.2 Gas chromatography performed on the volatile components of the drug

\section{CHAPTER 3 - RESULTS AND DISCUSSION}

3.1 Organoleptic evaluation of market samples and reference drug $\quad 47$

$\begin{array}{ll}3.2 \text { Total ash content } & 50\end{array}$

$\begin{array}{ll}\text { 3.3 Methanol extractable matter } & 50\end{array}$

3.4 Ethanol insoluble macro-molecular fraction 51

3.5 Thin Layer Chromatography 52 
3.6 Gas Chromatography

4 CHAPTER 4-CONCLUSION 56

5 CHAPTER 5 - SUGGESTIONS FOR FURTHER WORK 58

$\begin{array}{ll}\text { REFERENCE } & 59\end{array}$

$\begin{array}{ll}\text { APPENDIX } & 61\end{array}$ 


\section{List of Tables}

Table 1.5.1 - Ingredients of Kushmanda avaleha

Table 1.5.2 - Nutritional value for sugar $\quad 31$

Table 1.5.3 Chemical composition of cow ghee 32

Table 2.1 - Weights of avaleha samples used to determine total ash content

Table 2.2 - Weights of avaleha samples used to determine methanol extractable

Matter

Table 2.3 - Weights of Avaleha samples used to determine ethanol insoluble macro-molecular fraction

Table 3.1 - Taste, odour, touch, and consistency of reference drug and 5 market samples

Table 3.2 - Total ash content in reference drug and five market samples

Table 3.3 - Methanol extractable matter in reference drug and five market samples

Table 3.4 - Ethanol insoluble macro-molecular fraction in reference drug and five market samples

Table 3.6 - Summarized gas chromatogram data of market samples in relation to reference drug 


\section{List of figures}

Figure 1.5.1 - Benincasa hispida plant and fruit

Figure 1.5.2 - Piper longum plant and dried fruit

Figure 1.5.3 - Cumminum cyminum dried fruits

Figure 1.5.4 - Zingiber officinale plant

Figure 1.5.5 - Cinnamomum ceylanicum plant

Figure 1.5.6 - Elettaria cardamomum plant and dried fruit

Figure 1.5.7 - Piper nigrum plant and dried seeds 28

Figure 1.5.8 - Coriandrum sativum dried fruit 30

Figure 1.5.9 - Structures of main volatile components

Figure 3.1 - physical appearance of reference drug

Figure 3.2 - physical appearance of Brand 1

Figure 3.3 - physical appearance of Brand 2

Figure 3.4 - physical appearance of Brand 3

Figure 3.5 - physical appearance of Brand 4

Figure 3.6 - physical appearance of Brand 5

Figure 3.7 - Summarized chromatogram peaks of reference drug and 5 market samples

Figure A - Gas chromatogram of reference drug

Figure B - Gas chromatogram of brand 1

Figure C - Gas chromatogram of brand 2

Figure D - Gas chromatogram of brand 3

Figure $\mathrm{E}$ - Gas chromatogram of brand 4 


\section{Meanings of Sanskrit words and phrases}

- Bhaishajya-drugs

- Kalpana - method of preparation

- Panchavidha Kasaya Kalpana - the five types of Kasaya preparation methods. Here the word 'Kasaya' does not actually refer to decoction. The word stands for all the primary drug preparations such as Swarasa (juice), Kalka (paste), Kwatha (decoction), Hima (cold infusion) and Phanta (hot infusion). Therefore one cannot use the words 'five decoctions 'as a translation for Panchavidha Kasaya.

- Avaleha-Confections

- Sneha-types of oils

- Sandhana-preparation of Asava and Arishta

- Dosha - there are called the 'Humours' of the body. According to Ayurveda there are 3 Doshas called Vata, Pitta, and Kapha. These words cannot be translated to English as it may result in giving the reader a wrong sense of direction to their meanings. They are the vital energies of the body, if unbalanced causes diseases.

- Veerya-potency

- Ushna veerya - potency to increase Pitta dosha.

- Bhasma - a powder form made after the purification of certain mineral raw materials. 


\section{CHAPTER I}

\section{INTRODUCTION}

\subsection{Evolution of Ayurvedic Drug preparation and the present state}

Ayurveda, Allopathic medicine, Homeopathy are popular in society to achieve the same goal such as a healthy life. However, ayurveda is the oldest. It describes diseased conditions very elaborately. According to ayurveda, diseased state is described as "imbalance or loss of equilibrium of natural harmony of the human body, mind and the spirit". Ayurveda not only guide to maintain this harmony but also recommend normalizing the deranged harmony of life.

The science of life, ayurveda has specified Vaidyadi chathuspada, the four indispensables, which help to maintain or to normalize the equilibrium of body, spirit and mind. From these four indispensables, drugs (aushadha) come in second place.

The sciences Pharmacognosy, Pharmaceutics, Pharmacology come under drugs (aushadha) but the use of drugs (aushadha) in the natural form is not feasible. Accordingly, the intellectual minds have modified them into suitable and beneficial forms. This development takes the shape of a well developed branch termed as Bhaishajya kalpana $^{\text {ref }}$. Bhaishajya kalpana ${ }^{\text {ref }}$ is the art and science of preparing and dispensing medicine. The conversion of raw materials into drugs is continuous and step wise. Ancient scholars were capable of modifying the raw materials such as leaves, roots, barks, etc in to the form of swarasa (juice), kalka (paste), kwatha (decocticn), hima (cold infusion) and phanta (hot infusion) which are commonly named as Panchavidha Kasaya kalpana. ${ }^{\text {ref }}$

Biopharmaceutics also a part of Bhaishajya kalpana $^{\text {ref }}$, which is concerned with changes in therapeutic efficacy according to different formulation. In the broad sense, it 
also includes study of adjuvant, different procedures, and its therapeutic action. Avaleha, ${ }^{\text {ref }}$ Sneha ${ }^{\text {ref }}$ sandhana ${ }^{\text {ref }}$ kalpana,${ }^{\text {ref }}$ etc are modified forms of Panchavidha Kasaya kalpana ${ }^{\text {ref }}$ to maintain availability of drug materials throughout the year and to increase shelf life, good taste, elegant look and pleasant smell. These are produced using quick action with low doses. Despite this, different kalpana ${ }^{\text {ref }}$ has its own specific qualities. For instance, sneha ${ }^{\text {ref }}$ pacifies three doshas $^{\text {ref }}$ and has the capability to reach each body cell to nourish them.

Bhaishajya kalpana ${ }^{\text {ref }}$ is part and pride of every branch of ayurveda. The physician has the knowledge of diseases and knowledge of selection, collection and preparation of drug. In the past collection and manufacturing of the drug had been done on small scale depending on needs of people. Drugs were prepared by the physician himself or by others under his immediate supervision, with the intension of curing diseases. Since the raw materials were collected from a garden or from a forest, all raw materials were fresh. As long as the ingredients were readily available and when society moved at a leisurely pace, the simple methods of drug preparation were practicable.

At the present, rapid urbanization and deforestation has led to the scarcity of plant sources and escalation of their prices. Moreover, in a sophisticated urban society, purchase of manufactured drug is preferred to the time-consuming preparations. As a result, demand for finished products lead to a new phenomenon, which is manufacturing ayurvedic drugs in an industrial scale.

Production of ayurvedic drugs in large-scale has initiated the need to have experts to get therapeutic benefits. The entry of non-ayurvedic persons in the field led to the development of proprietary medicines without following ayurvedic ethics. 
Therefore, it is necessary to combine these sciences with the help of modern science such as physics and chemistry. Moreover, due to the competitiveness of private manufacturers, adulteration of expensive ingredients with cheaper ones, use of improper ingredients and careless procedures of preparation has become evident. Hence, the need to ensure the quality and safety of the product available in the market became urgent and imperative.

\subsection{Need for standardization}

Drugs either allopathic or ayurveda need standardization in order to supply a quality product to the consumer. It is more difficult to draw standards for ayurvedic medicines compared to western medicines, which normally contain no more than two or three active ingredients.

Standardization of herbal products is necessary to establish consistency and reproducibility of a particular extract to ensure guaranteed potency through acceptable level of active compounds. Hence, standardization will be advantages towards the following. ${ }^{1}$

- Guarantee potency/efficacy

- Implement quality control/assurance

- Ensure uniformity of dosage

- Check stability/Expiry dating

It is very important to establish a system of standardization for every plant medicine in the market, since the scope for variation in different batches of medicine is enormous. When plant material used in bulk quantity may vary in its chemical content so that its therapeutic effect will differ according to different batches of collection. For instance, efficacy of drugs made from raw materials collected in different seasons, 